\title{
THE VIEWS OF JUDGES AND PROSECUTORS ON THE OPINIONS OF PSYCHOLOGIST EXPERT WITNESSES IN CASES CONCERNING WITNESS TESTIMONY
}

\author{
Joanna KABZIŃSKA \\ SWPS University of Social Sciences and Humanities, Faculty of Psychology in Katowice, Poland
}

\begin{abstract}
The purpose of this qualitative research is to explore the perceptions of Polish judges and prosecutors regarding the role of psychologist expert witnesses in the evaluation of eyewitness testimony. Two main research questions were formulated: What are the criteria for selecting psychologist expert witnesses to participate in interviews and then to formulate expert opinions? What do judges and prosecutors expect from psychologist expert witnesses and their evaluations of eyewitness testimony? In-depth interviews were conducted involving judges $(N=31)$ and prosecutors $(N=30)$, both male $(N=35)$ and female $(N=26)$. Though other factors, such as availability, were also frequently mentioned, the judges and prosecutors declared that their choices of psychologist expert witnesses were predominantly determined by their professional abilities. These criteria correspond with the characteristics that judges and prosecutors claim to value the most in psychologist expert witnesses: their specialist fields, their experience, and their reliability in carrying out their work. It is of particular importance to the evaluation of witness testimony that judges and prosecutors recognize that, for an opinion to be complete, there is a need for psychological testing and diagnosis in addition to being present at interviews. However, judges and prosecutors do not always recognise the difference between legal conceptions of witness credibility and the assessments of it formulated by psychologist expert witnesses. The research provides an unique insight into the expectations of Polish judges and prosecutors regarding the role of psychologist expert witnesses in evaluating, and reporting on, witness testimony. To identify the aspects of psychologists' opinions that are particularly valued by judges and prosecutors can enable better cooperation and communication between psychologists and legal professionals.
\end{abstract}

\section{Keywords}

Evaluation of witness testimony; Psychologist expert witnesses; Prosecutors; Judges.

Received 27 August 2021; accepted 30 September 2021

\section{Introduction}

Polish criminal procedure requires the participation of a psychologist expert witness in the questioning of juvenile victims, of witnesses under the age of fifteen (Art. 185a and Art. 185b of the Code of Criminal Procedure), and victims of the offences defined in Articles 197-199 of the Criminal Code (Art. 185c of the Code of Criminal Procedure; for more on the grounds for the special modes of hearing see Budzyńska, 2018, Osiak-Krynicka, 2019). In addition to these special modes of hearing, the regulations provide for the optional participation of a psychologist expert witness in hearings where the trial authorities have doubts regarding the mental state, state of mental development, or capacity to perceive or reproduce observations of a witness (Art. 192, Paragraph 2 of the Code of Criminal Procedure).

Psychologist expert witnesses are expected to combine theoretical refinement with practical knowhow and to deliver their skills at the highest level. Unfortunately, current requirements for candidates to be psychologist expert witnesses do not appear to promote the highest standards in these areas. Unhappily, 
proposals to demand more of expert witnesses (not only of psychologist expert witnesses) are not reflected in Polish legislation (see: Grabowska, Pietryka, Wolny, 2014; Forensic Watch, 2015; NIK, 2015; PTP, 2014).

In their survey research conducted on a group of judges and prosecutors, Beata Pastwa-Wojciechowska and Magdalena Błażek (2010) found that selection of psychologist expert witnesses was primarily guided by their abilities, prompt report-writing, and availability. The judges and prosecutors also pointed to their reliability, their ability to defend their position before the court, the unambiguity of their opinions, and the clarity and quality of the language they use in them (Pastwa-Wojciechowska, Błażek, 2010). The conclusions that emerge from this investigation should, however, be treated with a dose of caution owing to the small sample size.

As with all other evidence compiled for a case, the opinions of expert witnesses are subject to discretionary assessment by the trial authority (Art. 7 of the Code of Criminal Procedure). To assess the opinions of expert witnesses presents a particular challenge to the trial authority because it must take a position on evidence formulated based on expert knowledge that it does not possess. The provisions of the Code of Criminal Procedure offer little guidance to trial authorities on the criteria to be applied when evaluating the evidence of an expert witness, on drawing up formal requirements for opinions (Art. 201 of the Code of Criminal Procedure), and on the grounds for reappointing expert witnesses or appointing fresh ones (Art. 201 of the Code of Criminal Procedure). As Alicja Czerederecka (2013) has indicated, to assess an opinion solely by these criteria may not be satisfactory for the trial authority, as it does not guarantee that shortcomings and errors in an expert's opinion, as well as (rare) cases of deliberate abuse or negligence, will be detected. Methodological criteria relevant to both Polish (Czerederecka, 2013) and American practices and experiences (Heilbrun, 1992; Marlowe, 1995) have been devised in the psychological literature that can aid trial authorities in their assessments of expert opinions. It is difficult to judge, however, how far these criteria are known to representatives of trial authorities and how far they are actually applied in evaluations of expert opinions.

Given our empirical knowledge of the criteria for the appointment of psychologist expert witnesses and for the evaluation of the opinions themselves is incomplete, it would appear to be a matter of some interest to gather the opinions of representatives of law enforcement authorities and the judiciary regarding these issues. The following research questions were therefore formulated:

1. What criteria guide the trial authorities when selecting psychologist expert witnesses in cases in which witness testimony is evaluated?

2. In the view of representatives of the trial authorities, what are the indicators of quality in forensic-psychological opinions of witness testimony?

\section{Materials and method}

The research relies on a qualitative approach in the form of an in-depth interview (IDI) based on a prepared script. The respondents were interviewed by three researchers in the period from March 2018 to October 2018. Each interview lasted for between forty-five minutes and one-hour and each was recorded on a Dictaphone ${ }^{\mathrm{TM}}$ for later transcription. The respondents' statements were then structured using a coding key and analysed using qualitative data analysis software (QDA Miner Lite).

\section{Sample}

The interviews were conducted with 31 judges from 10 district courts and with 30 prosecutors from 8 regional public prosecutors' offices in Poland. There was a slight predominance of men $(N=35)$ over women $(N=26)$ in the sample. Two years was the shortest term-in-post among the respondents and twenty-nine years the longest. Among the prosecutors the average term-in-post was 10.9 years, while among the judges (in the criminal division) it was 11.2 years. ${ }^{1}$

\footnotetext{
1 The intention was to conduct in-depth interviews at the district courts randomly selected in the first stage of the project (which involved the analysis of case files at the following courts: Poznań Grunwald-Jeżyce District Court, Piła District Court, Zamość District Court, Puławy District Court, Gdańsk Południe District Court, Grudziądz District Court, Kraków-Nowa Huta District Court, and Brzesko District Court) and at the regional public prosecutors' offices situated in the same towns as these district courts. This plan could not be carried out in full because at some of the courts and offices the number of judges or prosecutors willing to take part in the interviews was too small to satisfy the methodological requirements. The fact that a lower than intended number of interviews were conducted prompted a decision to randomly sample further courts and prosecutors' offices, which were then approached with requests to take part in an interview.
} 


\section{Results}

\section{Criteria for the selection of a psychologist expert witness}

Most frequently, the respondents reported that they were guided by the substantive abilities of expert witnesses, including their professional experience. For example "In relation to a juvenile I try to appoint (...) an expert who I know works with young people. When it comes to witnesses who may also be victims, if it concerns, for example, incidents of a sexual nature, I look for an expert who also deals with sexology" (c17).

Some of the judges and prosecutors interviewed declared that the appointment of a particular psychological expert is primarily determined by their previous experience with them: "If it is important to me that an opinion is really good and helpful, and I don't commission it just because the law requires it, then I appoint psychologists that I trust, that I know" (c46). By analogy, bad experiences constitute a negative criterion for the selection of an expert: "If an expert submits an opinion that does not stand up once, twice, or three times, then I won't appoint them a fourth time" (c22).

It would appear that knowledge of an expert's abilities originates not only from personal experience but also from opinions about them that are in circulation in the relevant social and professional circles: "Of course we are guided (...) by the way someone delivers an opinion, that is, by the quality of their work, because it is well known who gives poor and who gives well-written opinions" (c1). And taking another statement: "On our circuit there are people who have a certain reputation. So, for example, the best expert for questioning a child is $\mathrm{X}$, and for the other categories you can choose from experts X, Y, and Z" (c56).

Often, and this was pointed out mainly by prosecutors, the choice of a particular psychologist expert witness is dictated by recommendations from colleagues: "We talk among ourselves, a prosecutor who starts work takes advice from senior colleagues when choosing an expert" (c49).

It would seem that some of the judges and prosecutors select psychologist expert witnesses according to a case's complexity. They distinguish straightforward cases, which do not require experts with above-average abilities, from cases that - for a variety of reasons - are more complex and so require the appointment of an expert with a higher level of ability: "For 'run of the mill' hearings, when dealing with a witness to, say, abuse, I use local experts unless I see a particular problem with the case. If not, I use local ones. It is well known that they aren't so able. I am guided by the complexity of the case, and also by the age of the witness: the younger they are, the more able the expert needs to be" (c12). It is possible, based on some of the statements, to gain the impression that experts from the courts' lists are precisely the ones to be appointed to cases regarded as uncomplicated, while academic or specialist institutes are appointed to more involved ones: "It's an unwritten rule that we turn to experts from the list first, unless the nature of the case and the circumstances of the case indicate that we need the expertise of a team and not one person. In those situations we appoint an institute" (c17).

Many of the respondents also pointed to the availability of psychologist expert witnesses, which is an important criterion for selection: "I'm guided first of all by their availability. There aren't many psychologist expert witnesses and they usually don't have the time" (c1). In addition to their time, there is also the question of their location, which is significant to the trial authorities, the parties, and the participants in the proceedings in equal measure.

The respondents' statements also reveal that many of them have a psychologist expert witness with whom they enjoy and prefer working. This amicability is not, however, accidental: "Usually judges have their favourite expert witnesses, it's because of their experience of working with them" (c50).

Some of the reasons given for choosing a particular expert witness, such as routine, were quite mundane: "When you've been working for a long time in a particular area, in a particular region, and there are expert witnesses there who you've already worked with, there is always a shortlist of contacts ready and waiting who are already proven, you don't look for experts from the list" (c23). It might equally be a matter of reducing the number of stages and amount of work involved in appointing an expert witness: "But if I can work with the same expert witness, I usually do - to avoid difficulties and delays. Then you always work faster, I have all his personal details, we usually have a form already made up, for an order to award costs, for example, so everything goes more smoothly" (c21).

It can be inferred from the declarations of some of the judges and prosecutors who gave interviews that, whether in respect of their ability, reliability, or even availability, the choice of a psychologist expert witness does not rest on reflection. This was particularly the case with respondents who always rely on the specialist knowledge of a few people, or one person, and do not seek alternatives (or there are none): "It's just that when I started work here this expert witness was recommended to me" (c2) or: "(...) in the small town where I sit there's one person, who's a psychologist and 
child psychologist with many years of experience, so I turn to her for help" (c36). There were also a number of declarations suggesting that choosing a psychologist expert witness can be a matter of pure chance: "If the expert I've chosen isn't able to provide an opinion, I choose another at random from the list" (c18).

\section{Requirements for psychologist expert witnesses}

The judges and prosecutors who were interviewed also spoke of the range of abilities desirable in a psychologist expert witness. A number of aspects were mentioned, including thorough training, the ability to cooperate with the trial authorities, and - understood in broad terms - the diligent performance of professional duties.

Where the professional training of psychologist expert witnesses is concerned, it would appear that the interviewees particularly valued superior substantive skills, but also direct experience: “(...) their qualifications, their specialisation, and their academic title are all important, but mainly it's a question of how practised they are in dealing with real people - the people they may possibly need to examine" (c17). Experience of delivering forensic-psychological opinions is also highly regarded: "I had a situation where the expert witness didn't quite know what we were talking about with these 'perceptions' because she'd never provided an opinion to a court before" (c42).

In the declarations of the judges and prosecutors, many of the desirable capabilities sought in a psychologist expert witness were connected with cooperation and communication with the trial authorities. The respondents drew attention to ease of communication with expert witnesses: "open to discussion and questions" (c3), as well as - at a more prosaic level - to politeness " ... always cultured, tactful, never any problems" (c19). Where cooperation and communication with the trial authorities is concerned, attention was also drawn to the availability of expert witnesses: "It's easier when I have a psychologist on hand locally, which means we can exchange observations and experiences, and if it's necessary to add something to a case, it's definitely easier to get this done than if I was working with a psychologist expert witness from G. (...). Everyone knows that it's easier to get a local to turn up to a hearing and deliver an opinion" (c27).

The judges and prosecutors made clear the capabilities they expected psychologist expert witnesses to possess in respect of performing their professional tasks. Here they attached great importance to a comprehensive approach to the task at hand, for example: "First they prepare the child for the hearing, then the hearing takes place, and next there are a series of further meetings with the child. Only then is an opinion given" (c11). And in another example: "I also observe the work of the expert, I look to see if they are only listening, or if they are taking notes as well. I also try to notice whether they need a further meeting to do tasks or exercises to check the level of the child" (c25). They also pointed out the need for expert witnesses to formulate their conclusions based on data from specific sources: "When questioned by the court, the expert witness was able to be precise and to concretise what he objectively based his knowledge on" (c43). And in another statement: "I need an expert who says: 'I conducted a specific test, I evaluated the results on a specific scale, the examination took place in a specific way', which is a good way of operating for us, because not only are we convinced by the opinion, the court, and sometimes the other side, is too, so that the defence counsel cannot challenge it" (c58).

Impartiality and objectivity were also characteristics judges and prosecutors emphasised: "On one occasion the psychologist started asking what were obviously leading questions, which made me think at the time that the expert was trying too hard to extract information from the witness about facts he'd learned about from the case file. I also got the impression that the psychologist expert witness was beginning to influence the witness's testimony" (c20).

In the work of psychologist expert witnesses, the judges and prosecutors appeared to particularly appreciate commitment and active participation: "very committed to the work, inquisitive" (c39) and: "the expert is actually active during questioning as well - asking questions, making notes (...)" (c10). In response to a question designed to elicit the difficulties that arise when working with psychologist expert witnesses, the respondents underlined the significance of not simply accepting a task, but actually taking responsibility for it and carrying it out thoroughly and on time: "Not being punctual, taking too long to compile opinions, cancelling hearings, which all make the proceedings last a lot longer. If I have to talk about problems working with expert witnesses, it's mainly to do with unreliability" (c18).

Finally, the respondents stated the salience of being able to work well with the people they question and examine, and, especially, to establish a sympathetic relationship with them: "Having observed the work of several expert witnesses, I've noticed that their skills in establishing a rapport vary. Some achieve this naturally, which results in them handling the situation more easily, making the questioning run smoothly. Others maintain a distance, which makes it difficult 
for the witnesses themselves when they come to testify" (c24).

\section{Witness testimony and the quality of psychologist expert opinions}

The judges and prosecutors participating in the research were asked what it is that distinguishes a forensic-psychological opinion of high quality from one of low quality in respect of witness testimony. It would appear that completeness is the key feature of a good opinion. Indeed, incompleteness can be taken as the mark of a poor opinion - even where the unfinished material is satisfactory or above average. There are a number of ways of interpreting the idea of completeness as it is used here. Firstly, an opinion is complete when it contains responses to all of the questions: "The opinion answers all the questions put to the expert in the instruction. That is the most important thing. If these questions are addressed and answered in detail, the opinion is complete" (c24). Secondly, an opinion is complete where the expert witness takes account of all of the circumstances and facts that could be relevant in resolving the issue placed before the expert witness: "Sometimes an opinion is not complete, it does not include all of the facts and circumstances. Sometimes an expert witness will concentrate more on the question of confabulation of a witness, and overlook some other important facts or circumstances" (c32). Third, an opinion's completeness is also demonstrated by whether or not the expert has taken account of all of the evidence made available to them. In this context, a poor-quality opinion is one: "Without an analysis of previous opinions relating to, for example, cases that have been overturned - where this happens the expert witness has not referred at all to the earlier opinion, which may have reached a different conclusion to the one they have formulated" (c39) or: "(...) We assess whether this opinion takes into account other material that is available in the case, such as medical records" (c6). Fourthly, and lastly, an incomplete opinion is one that does not provide a full and thorough report of the examinations carried out: "They were very superficial opinions, with no explanation of the investigatory methods used and no in-depth analysis of the evidence (...)" (c39).

Another question that arose where the completeness (or incompleteness) of opinions is concerned is whether expert psychologist witnesses base their opinions only on observations of hearings or whether they also conduct psychological examinations: "I appreciate the fact that the expert witness checks, e.g. the child's emotional level or mental development, and that they meet the child as well as attending the hearing" (c25). It would appear that the representatives of the trial authorities (though not all of them) are aware that these examinations form an essential element of proper professional practice for psychologist expert witnesses providing opinions on witness testimony: "It seems to me that expert witnesses should conduct psychological examinations outside the courtroom before giving an absolutely clear and categorical opinion" (c13) or: "(...) The examination is, in my opinion, a really valuable source of knowledge for a psychologist" (c23).

The statements of respondents who described poor opinions using terms such as formulaic, lacking in detail, and rushed addressed their incompleteness in terms of their failure to take account of facts and circumstances relevant to determining the issue in question or to provide complete accounts of the work done. Many respondents mentioned opinions that were partial, or even full, copies of earlier opinions: "These opinions are all the same, as if they were produced by cutting and pasting - and that's their major defect (...), I've seen a lot of opinions on the truthfulness of witness testimony, but it's all very shallow and nondescript" (c11). Some even stated that expert witnesses use template opinions (and, what is more, do so in a fairly slipshod manner): "We all use computers and opinions are written just like prosecutor's orders, court orders or judgments. They are all based on models produced earlier. Editing opinions, judgments, orders or decisions in this way can generate mistakes when something that was written in a previous opinion is not deleted by the person writing the new one" (c59).

Further reference to incompleteness came in statements that cited thoroughness (understood as reference to diverse sources of knowledge about those under examination and taking account of various aspects weighing on the assessment) as a criterion of the quality of forensic-psychological opinions: "I usually look at how thoroughly an expert assesses the person, whether they only look at the content of the testimony, or do they also notice facial expressions and the way the witness behaves - the non-verbal reactions? This tells me whether the assessment really is holistic. I also pay attention to whether an expert is focused only on attending the hearing itself or whether they talk to the witness outside the courtroom to get an idea of how the witness functions as a person. Do they try to find out whether the witness is ill? Do they look at the documentation to find out what treatment the witness has been receiving? This is how I judge how thorough, detailed and meticulous an opinion is" (c37). Yet opinions of excessive, unjustified length (caused by the 
inclusion of redundant, unnecessary elements) should not be mistaken as exemplars of thoroughness and detail: "Sometimes expert witnesses write too much in their opinions; they scan or photocopy the testimonies wanting to add value to their opinions or in an attempt to demonstrate to the judge that they really have mastered the material. In my view it's unnecessary, because for me you can already see from the opinion whether the expert has read the material or whether the opinion goes beyond what is in the material" (c32).

The subject of the clarity of opinions was taken up many times by the respondents during the course of the research. According to Tadeusz Tomaszewski (1998), a clear opinion is one in which it is possible to follow an expert's line of argument through to its conclusions. In this connection, many of the respondents referred to the criterion of the logical connection between the report and an opinion's final conclusions "On the principle of straightforward deduction: if we have a particular set of premises and we derive a specific conclusion that follows logically from them, everything is in order" (c22). The respondents often stressed the need to place opinions properly within the context of the examinations carried out and the action taken, and the need for opinions to justify their final conclusions: "It is up to experts to show how they have arrived at their particular conclusions. An opinion, in addition to the conclusions themselves, must contain the whole process of arriving at those conclusions" (c12). The following statement, which also emphasises that the report section of an opinion should be consistent with its conclusions, puts this more precisely: "For me, a good opinion is one that describes the results of the examination, the various spheres of a witness's life, their personality, and their life history, and offers conclusions that go beyond whether a witness is psychologically credible or not. In opinions, good conclusions refer to the cognitive aspects of a witness that determine their ability to remember and, if this is low, state the reason why. Conclusions should be consistent with the report section and include everything that is relevant. If organic changes have been detected in someone's brain, the conclusion should state whether they are capable of influencing anything and, if they are, state what it is they can influence" (c57). It is for these reasons that psychological opinions of the following type are unacceptable: “(...) There are also some that simply summarise what the witness has testified, before drawing conclusions and giving unclear and imprecise answers to the court's questions. In my view, opinions like these do not contribute much, because the final conclusions in no way follow from the descriptive part" (c40).
The clarity of an opinion as a criterion for assessing its quality was a point of reference for a number of the judges and prosecutors who took part in the research. One aspect of this comprehensibility is definitely the use by expert witnesses of language that can be understood, so that "the opinion answers the court's questions as fully, and as unambiguously, as possible in fairly simple language" (c51) and so that "it is written in language that does not have to be too academic, the more straightforward the better, because an opinion is not just for the court, but also for the parties, everyone must be able to understand what it says" (c51).

The judges and prosecutors who took part in the research expressed contradictory opinions on the definiteness of psychologist expert opinions. Many representatives of the procedural authorities particularly appreciate expert witnesses who provide unequivocal assessments that allow for only one possible interpretation: "Most opinions are unambiguous and that is certainly very important because it makes the judge's job easier" (c32) or: "The best opinions are when the conclusions are incontrovertible; the worst are when they are fuzzy" (c8). The judges and prosecutors also expected a firm declaration in cases where it is not possible to issue a definite opinion: "If an expert witness does not know, let them write that they don't know. And having seen the case files of colleagues preparing for hearings, I've noticed more than once opinions that were not categorical. I'm well aware that sometimes it's impossible to provide an unequivocal opinion, but then it's necessary to write clearly that it's impossible" (c20). In stating that it is unacceptable to draw unequivocal conclusions in forensic-psychological opinions of witness testimony, other respondents took quite the opposite view: "In a psychological opinion, categorical conclusions are unprofessional" (c43). It is possible that this polarity is superficial only. The impossibility of answering questions posed by the trial authorities (when the data do not support clear conclusions) should be distinguished from excessive interpretive caution on the part of an expert witness. It would appear important to judges and prosecutors that expert witnesses remain within the bounds of their fields of professional knowledge.

It would appear particularly important to judges and prosecutors that expert witnesses remain within the bounds of their fields of professional knowledge. They understand this, firstly, as not offering opinions on matters that fall within the disciplinary ambit of another expert witness: "When I check an opinion, I think about whether it exceeds the specialist knowledge of the expert witness and whether an expert witness from another field might be necessary" (c33). 
And, secondly, not encroaching on the domain of the trial authority, that is, not formulating assessments as to the facts of a case: "They don't try to put things in an opinion that we don't ask them about or that they haven't been appointed to consider. They don't place their views on the subject of the proceedings in their opinions" (c48) and not taking a view on the credibility of the testimony of particular witnesses: "An opinion should definitely not state that somebody is lying or providing false testimony, because an expert witness cannot ascertain that - it's the task of the judge. And sometimes that sort of information does appear (...)" (c26). The majority of judges and prosecutors are able to state where the line that separates the preserve of the trial authority from that of a psychologist expert witness is drawn: "If a psychologist states categorically that, in a particular respect, someone is credible or not, it puts me on my guard. It seems to me that a psychologist should point to factors that support such a conclusion, or suggest certain things, and leave the rest to me to assess. I think there should be a line between our domains that we should not cross" (c16). The statements of the judges and prosecutors create the impression that some of them do not perceive the differences between legal and psychological assessment, which they treat as merely a matter of using the correct vocabulary: "All expert witnesses need to do is to take care (as is also sometimes evident from the vocabulary used) not to write 'I find the witness credible', as if they were speaking for the court, and instead to write, "they meet the criteria for psychological credibility"' (c19). Unfortunately, there are those (especially among prosecutors) who all but demand assessments of credibility from expert witnesses: "There's an expectation in most cases that the credibility or otherwise of a witness will be stated explicitly. This statement is always made, but it is good if it is explained beforehand why" (c23).

The quality of an opinion may also be reflected in whether it convinces the trial authority and whether it will convince the court at the main session: "A poor opinion is one that convinces me of nothing. Or if I read it and afterwards I have doubts. Then I know: if I have doubts, the court will have them all the more" (c58).

\section{Discussion}

The qualitative research presented here confirms previous reports on the criteria applied by representatives of trial authorities when selecting expert witnesses. These criteria correspond with the statements of the respondents concerning the qualities sought in psychologist expert witnesses, which largely refer to their substantive competencies: specialisations, professional experience, reliable performance of their duties as expert witnesses, and their ability to cooperate with the trial authorities, the parties, and the participants in trial proceedings. These declarations that psychologist expert witnesses are selected based on their abilities is confirmed by research conducted in other countries and jurisdictions, such as Australia (Gianvanni, Sharman, 2017). Yet the above study found that despite declaring that ability is the key factor when selecting expert witnesses, lawyers have no knowledge of how psychologists can obtain the clinical or forensic specialisation they regard as desirable.

The opinions expressed in the present study are consistent with the findings of research done by the Forensic Watch Foundation (2015) on the assessment of the institution of the expert witness. It emerges from surveys of judges, prosecutors, and lawyers that the two most serious problems encountered in the functioning of the institution of the expert witness are factual errors in reports (unclear argumentation, ambiguous conclusions, incomplete opinions) and long waiting times for them.

It would appear that selection based on general opinion or recommendations from colleagues is also widespread beyond Poland (Gianvanni, Sharman, 2017). It is difficult to blame judges or prosecutors for this, since the system whereby the institution of the expert witness functions neither promotes the candidates who are best on merit nor provides effective tools to remove expert witnesses who fail to perform their duties properly. The belief expressed by the respondents that less complex cases are 'reserved' for expert witnesses from the court lists would appear to confirm the low opinion held of the system whereby the institution of the expert witness functions.

In their declarations on the quality of forensic-psychological opinions, the judges and prosecutors made clear reference to those characteristics of expert opinions that correspond with the legal criteria for their assessment - as defined in Art. 201 of the Code of Criminal Procedure (completeness versus incompleteness, clarity versus ambiguity, and non-contradictoriness versus contradictoriness), as interpreted in the case law, e.g. in Supreme Court Judgment III KK $12 / 09$ of 7.10.2009, and as developed in the legal literature (Gaberle, 2010; Tomaszewski, 1998; Witkows$\mathrm{ka}, 2013)$. The respondents made no reference to the methodological criteria set out in the literature for assessing forensic-psychological opinions. There is thus a need to train representatives of the trial authorities in 
the means available for producing in-depth analyses of them.

The features of poor quality and high-quality psychological opinions of witness testimony indicated by the respondents are not characteristic of the Polish case alone. Studies conducted in Australia have determined the significance of properly justified conclusions that are supported by test results, of expert witnesses remaining within their areas of expertise, of the objectivity of expert witnesses, and of lucid language in reports (Gianvanni, Sharman, 2017; Freckelton, Reddy, Selby, 1999). The conclusion may be cautiously drawn, then, that certain of the problems attaching to the production of expert opinions are universal.

The respondents' statements on the boundaries between the respective domains of psychologist expert witnesses and the trial authorities, which some representatives of the latter understand as a matter only of using the correct language, are particularly noteworthy. The question is, however, more complicated than that. The predominant line taken in the case law is that assessment of the credibility of witness testimony is the exclusive preserve of the adjudicating court, which performs this task based on the entire body of evidence (e.g. Judgment of the Kraków Court of Appeal, II Aka 149/14 of 21.10.2014). Assessment of the credibility of testimony does not lie within the competency of psychologist expert witnesses. In other words, their role is not to state the extent to which the testimony corresponds with the real course of an event (e.g. Judgment of the Kraków Court of Appeal, II Aka 360/02 of 15.01.2003). An analogous judgment, that a psychologist expert witness is not entitled to make cardinal assessments of the probative value of witness testimony, since the conclusions they draw in an opinion cannot refer - other than in cases of pathology - to the possibility that such testimony is untruthful because decisions in that area can depend on the interpretation of other evidence made known in a case, was made by the Katowice Court of Appeal (II Aka, 12.05.2005). It should be stressed, however, as if to counter the above judgment, that the credibility of testimony (or its absence) is not identical to its truthfulness or its sincerity (Maciejski, 2009). For an assessment of testimony to be complete, it should take account of all three of these qualities, which are not identical. Truthfulness obtains where the content of testimony corresponds with the factual course of events. Sincerity, meanwhile, is to be comprehended as correspondence between the content of testimony and the subjective belief in the truthfulness or falsehood of the account given. And, finally, credibility is the likelihood, assigned by the trial authority, that the testimony of a witness is a reflection of reality. The body conducting the proceedings takes a position on this likelihood based on an assessment of the entire body of evidence pertaining to the case (Wojciechowski, 2016). The trial authority's decision to attribute a certain level of credibility to testimony can be independent of the intentions of the witness to present the event honestly or untruthfully on the one hand, and of the objective truthfulness of their account on the other (Wojciechowski, 2016).

Having particular regard to the fact that assessment of credibility is the exclusive preserve of the trial authorities, legal evaluations of witness testimony should address the truthfulness, sincerity, and credibility of testimony. The role of assessments produced by psychologist expert witnesses in the course of forming a forensic-psychological opinion is, however, one of support. Their purpose is to facilitate the formulation of assessments by the trial authorities, to properly prepare the ground for a legal assessment of testimony, and to focus on identifying the variables that determine the most important features of the account (Wojciechowski, 2016).

It is also worth noting that the judges and prosecutors interviewed in the survey were quite unanimous on the need, if they are to issue forensic-psychological opinions, for psychologist expert witnesses to conduct psychological examinations in addition to participating in the hearing itself. While it is true that Art. 192 Paragraph 4 of the Code of Criminal Procedure states that expert witnesses can, but are not obliged to, conduct psychological tests on a witness, it should nevertheless be acknowledged that the absence of such tests is regarded as grounds for judging an opinion incomplete (Jaśkiewicz-Obydzińska, Wach, 2013). In fact, the necessity for expert witnesses to conduct psychological tests is a basic principle observed in the preparation of opinions for court purposes (Jaśkiewicz-Obydzińska, Wach, 2013).

Though the research presented here represents an important addition to existing knowledge on the criteria for the selection of psychologist expert witnesses and the way in which representatives of the trial authorities assess the quality of their opinions, it has taken no account of the other side, that is, it does not include in-depth interviews with expert psychologists. To learn of each other's point of view could contribute to improved communication and cooperation between lawyers and psychologists. To compare and contrast our mutual expectations and the options for satisfying them requires, however, that both sides acquire a thorough knowledge of the existing practice of producing forensic-psychological opinions in matters relating to 
the psychological assessment of testimony, which can be accomplished, for example, by studying case files.

\section{Acknowledgements}

This research was financed by the National Science Centre (grant ID: 2015/19/D/HS5/01241).

\section{References}

1. Budzyńska, A. (2018). Rola i zadania biegłego psychologa w przesłuchaniu małoletniego świadka. (In) A. Budzyńska (Ed.), Przestuchanie małoletniego świadka w postępowaniu karnym. Poradnik dla profesjonalistów (pp. 45-56). Warszawa: FDDS.

2. Czerederecka, A. (2013). Evidence evaluation criteria for expert opinions prepared by psychologists. Problems of Forensic Sciences, 93, 333-350.

3. Forensic Watch (2015). Ocena kompetencji bieglych sądowych. Oczekiwania $i$ rekomendacje. Warszawa: Fundacja Europejskie Centrum Inicjatyw w Naukach Sądowych. Retrieved July 26, 2021 from: http://forensicwatch.pl/web/pliki/baza-wiedzy/Opracowania/Ocena -Kompetencji-Bieglych-Sadowych.pdf.

4. Freckelton, I., Reddy, P., Selby, H. (1999). Australian judicial perspective on expert evidence: An empirical study. Melbourne: The Australian Institute of Judicial Administration Incorporated.

5. Gaberle, A. (2010). Dowody w sadowym procesie karnym. Teoria i praktyka. Warszawa: Wolters Kluwer.

6. Gianvanni, E., Sharman, S. J. (2017). Legal representatives' opinions regarding psychologists engaging in expert witness services in Australian courts and tribunals. Psychology, Psychiatry \& the Law, 24(2), 223-232.

7. Grabowska, B., Pietryka, A., Wolny, M. (2014). Biegli sqdowi w Polsce. Warszawa: Polska Rada Biznesu i Helsińska Fundacja Praw Człowieka. Retrieved July 26, 2021 from: https://www.hfhr.pl/wp-content/uploads/2014/04/ HFPC_PRB_biegli-sa\%CC\%A8dowi_w_polsce.pdf.

8. Heilbrun, K. (1992). The role of psychological testing in forensic assessment. Law and Human Behavior, 16, $257-272$

9. Jaśkiewicz-Obydzińska, T., Wach, E. (2013). Ocena rzetelności opinii psychologicznej. Na Wokandzie, 15. Retrieved July 26, 2021 from: https://nawokandzie.ms.gov. pl/numer-15/dobre-praktyki-15/ocena-rzetelnosci-opinii -psychologicznej.html.

10. Maciejski, M. (2009). Psychologiczna analiza sposobów przestuchania świadków i reguł oceny ich zeznań w praktyce sędziowskiej a stopień przypisywanej im wiarygodności. Niepublikowana praca doktorska. Katowice: Uniwersytet Śląski.
11. Marlowe, D. B. (1995). A hybrid decision framework for evaluating psychometric evidence. Behavioral Sciences \& the Law, 13, 207-228.

12. Najwyższa Izba Kontroli (2015). Funkcjonowanie biegłych w wymiarze sprawiedliwości. Informacja o wynikach kontroli. Warszawa: Departament Porządku i Bezpieczeństwa Wewnętrznego NIK. Retrieved July 26, 2021 from: https://www.nik.gov.pl/plik/id,9608,vp,11856.pdf.

13. Osiak-Krynicka, K. (2019). Nowe zasady przesłuchania w trybie art. 185c Kodeksu postępowania karnego osoby pokrzywdzonej przestępstwem z art. 197-199 Kodeksu karnego. Folia Juridica Universitatis Wratislaviensis, 8(2), 149-163.

14. Pastwa-Wojciechowska, B., Błażek, M. (2010). Profesjonalizm czy brak profesjonalizmu? Najczęstsze błędy formalne i metodologiczne opiniowania psychologiczno -sądowego w sprawach karnych. (In) B. Gulla, I. Niewiadomska, M. Wysocka-Pleczyk (Eds.), Białe plamy psychologii sądowej (pp. 23-32). Kraków: Wydawnictwo UJ.

15. Polskie Towarzystwo Psychologiczne (2014). Warunki przyznawania rekomendacji PTP psychologom ubiegajacym się o petnienie funkcji biegłych sądowych. Retrieved July 26, 2021 from: http://www.ptp.org.pl/modules. php? name $=$ News\&file $=$ article $\&$ sid $=45$.

16. Rode, D., Dukała, K., Kabzińska, J., Zalewska-Łunkiewicz, K. (2020). Kliniczna psychologia sadowa. Warszawa: PWN.

17. Tomaszewski, T. (1998). Dowód z opinii biegłego w procesie karnym. Kraków: Wydawnictwo IES.

18. Witkowska, K. (2013). Biegły w postępowaniu karnym. Prokuratura i Prawo, 1, 65-81.

19. Wojciechowski, B. W. (2016). Analiza i ocena zeznań świadków. Sopot: GWP.

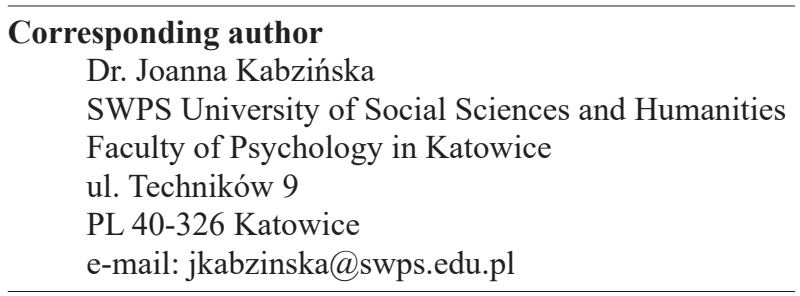




\section{OPINIA BIEGLEGO PSYCHOLOGA W SPRAWACH DOTYCZACYCH ZEZNAŃ ŚWIADKÓW W OPINII PROKURATORÓW I SĘDZIÓW}

\section{Wprowadzenie}

Polska procedura karna przewiduje obligatoryjny udział biegłego psychologa $\mathrm{w}$ przesłuchaniu w przypadku małoletnich pokrzywdzonych i świadków poniżej 15 roku życia (art. 185a-b k.p.k.) oraz osób pokrzywdzonych przestępstwami z art. 197-199 k.k. (art. 185c k.p.k.; szerzej na temat przesłanek szczególnych trybów przesłuchania zob. Budzyńska, 2018; Osiak-Krynicka, 2019). Obok wspomnianych szczególnych trybów przesłuchania przepisy przewidują fakultatywny udział biegłego psychologa $\mathrm{w}$ przesłuchaniu w przypadku, gdy organ procesowy poweźmie wątpliwości co do stanu psychicznego świadka, jego stanu rozwoju umysłowego lub zdolności postrzegania lub odtwarzania spostrzeżeń (art. 192 § 2 k.p.k.).

Biegły psycholog powinien legitymować się najwyższymi kompetencjami w zakresie wiedzy teoretycznej, jak i umiejętności praktycznych. Niestety, trudno uznać obowiązujące wymagania stawiane kandydatom na biegłych za promujące najwyższe standardy w tym zakresie. Propozycje dotyczące zwiększenia wymagań stawianych biegłym (nie tylko biegłym psychologom) nie znajdują niestety odzwierciedlenia w rodzimym ustawodawstwie (zob. szerzej: Grabowska, Pietryka, Wolny, 2014; Forensic Watch, 2015; NIK, 2015; PTP, 2014).

$\mathrm{Z}$ badań ankietowych przeprowadzonych $\mathrm{w}$ grupie sędziów i prokuratorów przez Pastwę-Wojciechowską i Błażek (2010) wynika, że powołując biegłego psychologa, kierują się oni przede wszystkim jego kompetencjami, szybkością sporządzania opinii i dostępnością. Badani wskazywali również na rzetelność biegłego, umiejętność obrony własnego stanowiska przed sądem, jednoznaczność opinii oraz jasność i poprawność języka opinii (Pastwa-Wojciechowska, Błażek, 2010). Ze względu na niewielką próbę badawczą wnioski płynące $\mathrm{z}$ tych badań należy jednak traktować z pewną dozą ostrożności.

Opinie biegłych podlegają swobodnej ocenie organu procesowego, tak jak i wszystkie inne dowody zgromadzone w sprawie (art. 7 k.p.k.). Ocena opinii biegłych jest dla organu procesowego szczególnie trudna ze względu na fakt, że ma za zadanie ocenić dowód sformułowany w oparciu o wiadomości specjalne, którymi nie dysponuje. Przepisy kodeksu postępowania karnego w niewielkim stopniu wskazują, jakimi kryteriami powinien się on kierować w ocenie dowodu $\mathrm{z}$ opinii biegłego, formułując wymogi formalne stawiane opiniom (art. 200 k.p.k.) oraz przesłanki ponownego powołania tych samych lub innych biegłych (art. 201 k.p.k.). Jak wskazuje Czerederecka (2013), ocena opinii wyłącznie przez pryzmat tych kryteriów może być dla organu procesowego mało satysfakcjonująca, gdyż nie gwarantuje ona możliwości wychwycenia braków i błędów w opinii biegłego, jak i (rzadkich) celowych nadużyć czy zaniedbań. W literaturze psychologicznej sformułowano dotychczas kryteria metodologiczne, które mogą ułatwić organom procesowym ocenę opinii biegłego psychologa i to zarówno w praktyce amerykańskiej (Heilbrun, 1992; Marlowe, 1995), jak i polskiej (Czerederecka, 2013). Trudno przesądzić jednak, na ile kryteria te znane są przedstawicielom organów procesowych i rzeczywiście stosowane $\mathrm{w}$ procesie oceny dowodu z opinii biegłego.

Gdy się weźmie pod uwagę niepełne dane empiryczne dotyczące kryteriów powołania biegłych psychologów i oceny samych opinii, interesujące wydaje się poznanie opinii przedstawicieli organów ścigania i wymiaru sprawiedliwości w odniesieniu do tych zagadnień. Sformułowano zatem następujące pytania badawcze:

1. Jakimi kryteriami kierują się organy procesowe przy wyborze biegłego psychologa $\mathrm{w}$ sprawach dotyczących oceny zeznań świadków?

2. Jakie są wskaźniki jakości opinii sądowo-psychologicznych dotyczących zeznań świadków w ocenie przedstawicieli organów procesowych?

\section{Materiały i metoda}

Badania przeprowadzono $\mathrm{z}$ wykorzystaniem metody jakościowej - wywiadu pogłębionego (in-depth interview, IDI). Podstawą wywiadu był wcześniej przygotowany scenariusz. Wywiady z respondentami prowadzone były w okresie od marca do października 2018 roku przez 3 badaczki. Czas trwania każdego z nich to około 45 minut do 1 godziny. Wywiady były nagrywane dyktafonem, a nagrania posłużyły do przygotowania transkrypcji. Wypowiedzi osób badanych zostały następnie usystematyzowane przy użyciu klucza kodowego i przeanalizowane $\mathrm{z}$ wykorzystaniem oprogramowania wspierającego analizę danych jakościowych (QDA Miner Lite).

\section{Próba}

Wywiady przeprowadzono z 31 sędziami z 10 sądów rejonowych i 30 prokuratorami z 8 prokuratur rejonowych w Polsce ${ }^{1}$. Wśród osób badanych była nieznaczna

\footnotetext{
${ }^{1}$ Założeniem było przeprowadzenie wywiadów pogłębionych w losowo wybranych sądach rejonowych, w których w poprzed-
} 
przewaga mężczyzn $(N=35)$ nad kobietami $(N=26)$. Najkrótszy staż pracy w badanej próbie to 2 lata, najdłuższy - 29. Średni staż pracy prokuratorów wynosił 10,9, sędziów (w wydziale karnym) - 11,2.

\section{Wyniki}

\section{Kryteria wyboru biegłego psychologa}

Respondenci najczęściej wskazywali, że kierują się merytorycznymi kompetencjami biegłego, w ramach których mieści się jego doświadczenie zawodowe, np. „W stosunku do małoletniego staram się powoływać (...) biegłego, o którym wiem, że współpracuje z młodzieżą. Gdy chodzi o świadków, którzy mogą być jednocześnie pokrzywdzonymi, jeśli dotyczy to np. zdarzeń o charakterze seksualnym, szukam biegłego, który również zajmuje się seksuologią" (c17).

Niektórzy indagowani sędziowie i prokuratorzy deklarują, że o powołaniu konkretnego biegłego psychologa decyduje przede wszystkim ich uprzednie doświadczenie w pracy z konkretnym ekspertem: ,Jeżeli zależy mi na tym, żeby opinia była naprawdę dobra i pomocna, a nie zlecam jej tylko dlatego, że ustawa tego wymaga, to powołuję psychologów, do których mam zaufanie, których znam" (c46). Złe doświadczenia stanowią - analogicznie - kryterium negatywne wyboru biegłego: ,Jeżeli biegły raz, drugi czy trzeci zrobi opinię, która się nie ostoi, to za czwartym razem go nie powołam" (c22).

Źródłem wiedzy o tych kompetencjach wydają się nie tylko własne doświadczenia z konkretnym biegłym, ale niekiedy także obiegowe opinie w środowisku na jego temat: „Oczywiście kierujemy się (...) tym, w jaki sposób ktoś opiniuje, czyli jakością jego pracy, bo wiadomo powszechnie, kto wydaje słabe, a kto dobrze napisane opinie” (c1) lub inna wypowiedź: „U nas są osoby, które mają pewną renomę, tzn. do przesłuchania dziecka najlepsza jest biegła $X$, do pozostałych kategorii można wybrać spośród biegłych X, Y, Z” (c56).

Często - a wskazywali na tę okoliczność głównie prokuratorzy - wybór konkretnego biegłego psychologa podyktowany jest poleceniem danej osoby przez współpracowników: „Rozmawiamy między sobą, prokurator,

nim etapie realizacji projektu przeprowadzono analizę akt sądowych (SR Poznań Grunwald-Jeżyce, SR Piła, SR Zamość, SR Puławy, SR Gdańsk Południe, SR Grudziądz, SR Kraków-Nowa Huta, SR Brzesko) oraz prokuraturach rejonowych w tych samych ośrodkach, w których zlokalizowane są sądy rejonowe. Założenie to nie w pełni udało się zrealizować ze względu na to, że nie we wszystkich ośrodkach zakładana liczba sędziów (prokuratorów) wyraziła chęć udziału w wywiadach. Wobec niższej (od zakładanej) liczby przeprowadzonych wywiadów przeprowadzono losowanie kolejnych ośrodków (zarówno sądów, jak i prokuratur), do których zwrócono się z prośbą o udział w wywiadzie. który rozpoczyna pracę, przy wyborze biegłego korzysta z rad starszych kolegów i koleżanek" (c49).

Wydaje się, że niektórzy indagowani sędziowie i prokuratorzy uzależniają wybór konkretnego biegłego psychologa od stopnia złożoności sprawy. $Z$ jednej strony wyróżniają sprawy nieskomplikowane, w których kompetencje biegłego nie muszą być ponadprzeciętnie wysokie, z drugiej zaś wskazują na sprawy bardziej złożone (z różnych przyczyn), które wymagają powołania biegłego o wyższym poziomie kompetencji: ,,Do takich 'zwykłych' przesłuchań, gdy mamy do czynienia ze świadkiem np. znęcania, korzystam z miejscowych biegłych, chyba że dostrzegam jakiś szczególny problem z tą sprawą. Jeżeli nie, to sięgam po miejscowych, wiadomo, że ich kompetencje są niższe. Kieruję się złożonością sprawy, a także wiekiem świadka, im jest on młodszy, tym większych wymaga kompetencji” (c12). Można, na podstawie niektórych wypowiedzi, odnieść wrażenie, że biegli sądowi powoływani są właśnie do spraw uznanych za nieskomplikowane, do bardziej złożonych natomiast powołuje się instytucje naukowe lub specjalistyczne: „Niepisaną regułą jest to, że w pierwszej kolejności powołuje się biegłych z listy, chyba że z charakteru sprawy, z jej okoliczności, wynika, że potrzebna jest wiedza pogłębiona nie jednego biegłego, a zespołu. W takich sytuacjach powołuje się instytut" (c17).

Wielu respondentów wskazywało również na dostępność biegłego psychologa, która jest istotnym kryterium jego wyboru: „Przede wszystkim kieruję się ich dostępnością. Psychologów biegłych jest mało i z reguły nie mają czasu" (c1). Istotne znaczenie, obok dostępności czasowej, ma również dostępność „,miejscowa” biegłego $-z$ jednej strony dla organów procesowych, ale także dla stron i uczestników postępowania.

Z wypowiedzi badanych wynika także, że wielu z nich ma preferowanych biegłych psychologów, z którymi lubią współpracować. Ta „sympatia” nie ma wszakże arbitralnego charakteru: „Zazwyczaj jest tak, że sędziowie mają swoich ulubionych biegłych, wynika to $\mathrm{z}$ doświadczeń w pracy z tymi biegłymi" (c50).

Niektóre z powodów zwracania się do konkretnych biegłych były prozaiczne, np. przyzwyczajenie: „Gdy ktoś pracuje dłuższy czas na jakimś terenie, w określonym okręgu, i są tam biegli, z którymi już współpracował, to zawsze dysponuje kilkoma wypróbowanymi wcześniej kontaktami, nie szuka biegłych z listy" (c23) lub uproszczenie przebiegu czynności związanych z powołaniem biegłego: „Ale jeżeli mogę pracować z tym samym biegłym, to zwykle to robię, żeby uniknąc trudności lub opóźnień. Wtedy zawsze pracuje się szybciej, mam jego pełne dane, mamy zwykle jakiś wzór postanowienia, np. w przedmiocie przyznania kosztów, dzięki czemu wszystko przebiega sprawniej" (c21).

Z wypowiedzi niektórych udzielających wywiadu sędziów i prokuratorów można wywnioskować, że 
wybór biegłego psychologa nie jest poparty refleksją, czy to w odniesieniu do kompetencji, rzetelności, czy nawet dostępności biegłego. Dotyczy to w szczególności tych indagowanych rozmówców, którzy stale korzystają $\mathrm{z}$ wiadomości specjalnych jedynie kilku lub jednej osoby i nie szukają alternatyw (lub ich nie ma): „Po prostu gdy zacząłem pracować, polecono mi tego biegłego" (c2) lub: „(...) w przypadku małej miejscowości, w której orzekam, jest jedna osoba - psycholog i psycholog dziecięcy $\mathrm{z}$ wieloletnim doświadczeniem, więc korzystam z jej pomocy" (c36). Zdarzały się również wypowiedzi wskazujące na to, że wybór konkretnego biegłego psychologa jest zupełnie przypadkowy: ,Jeżeli wybrany przeze mnie biegły nie jest $\mathrm{w}$ stanie podjąć się wykonania opinii, to wybieram losowo innego z listy" (c18).

\section{Oczekiwania względem biegłego psychologa}

Indagowani sędziowie i prokuratorzy wypowiadali się również na temat pożądanych cech samych biegłych psychologów. Oczekiwane cechy biegłych dotyczyły kilku aspektów: przygotowania zawodowego, umiejętności współpracy $\mathrm{z}$ organem procesowym oraz szeroko rozumianego rzetelnego wykonywania obowiązków zawodowych.

Wydaje się, że w aspekcie przygotowania zawodowego biegłych psychologów badani szczególnie cenią wysokie kompetencje merytoryczne biegłego, w tym doświadczenie zawodowe: „(...) ważne jest, jakie ma uprawnienia, jaką specjalizację oraz jaki tytuł naukowy, ale głównie - jakie ma doświadczenie z określonymi osobami, które ewentualnie mogą być poddane badaniu" (c17). Cenione jest również doświadczenie w opiniowaniu sądowo-psychologicznym: „Miałem taką sytuację, w której biegła nie do końca wiedziała, o co nam chodzi, z tymi 'postrzeżeniami', bo wcześniej nie sporządzała na potrzeby sądu opinii”" (c42).

Wiele $\mathrm{z}$ pożądanych cech biegłego psychologa wskazywanych przez sędziów i prokuratorów dotyczyło aspektu współpracy i komunikacji z organem procesowym. Badani zwracali uwagę na komunikatywność biegłego: ,jest otwarty na rozmowę i pytania” (c3), czy też - może nieco prozaiczną - uprzejmość: „Zawsze jest kulturalnie, taktownie, bez żadnych problemów" (c19). Zwracano również w tym aspekcie uwagę na dyspozycyjność biegłego: „Łatwiej jest, gdy mam psychologa na miejscu, dzięki temu możemy wymieniać się doświadczeniami, a w razie potrzeby uzupełnienia czegoś do sprawy na pewno łatwiej jest to uzyskać niż gdybym współpracowała z biegłym psychologiem z G. (...). Wiadomo, że takiemu biegłemu łatwiej się jest stawić na przesłuchanie, na wydanie opinii" (c27).

Sędziowie i prokuratorzy wyraźnie podkreślali, jakie są oczekiwane cechy biegłych psychologów w aspekcie wykonywania obowiązków zawodowych. Wielokrotnie akcentowali wagę kompleksowego podejścia biegłego do postawionego przed nim zadania: „Najpierw przygotowują dziecko do przesłuchania, potem następuje przesłuchanie, potem jeszcze następuje szereg spotkań z tym dzieckiem i dopiero jest wydawana opinia" (c11) lub inna wypowiedź: „Przyglądam się też pracy tego biegłego, obserwuję, czy on tylko słucha, czy notuje, czy potrzebuje dodatkowego spotkania, aby przeprowadzić ćwiczenia lub zadania weryfikujące poziom tego dziecka" (c25). Wskazywali również na konieczność formułowania wniosków opinii na podstawie danych pochodzących z konkretnych źródeł: „Biegły, pytany przez sąd, potrafił sprecyzować, skonkretyzować, na czym opierał obiektywnie swoją wiedzę" (c43) lub inna wypowiedź: „Potrzebuję biegłego, który powie: 'przeprowadziłem określony test, oceniłem wyniki w określonej skali, badanie przebiegało w konkretny sposób' - taki styl działania jest dla nas satysfakcjonujący, bo nie tylko przekonuje nas wydana wówczas opinia, ale jest ona także w stanie przekonać sąd, a nieraz zdarzało się, że i drugą stronę, tak że obrońca nie mógł jej zakwestionować" (c58).

Sędziowie i prokuratorzy podkreślali również wagę bezstronności i obiektywizmu biegłego: „Zdarzyła mi się sytuacja, w której psycholog zaczął zadawać pytania wyraźnie sugerujące treść odpowiedzi. To spowodowało, że faktycznie wówczas uznałam, że biegły za bardzo próbuje wyciągnąć ze świadka informacje na temat okoliczności, o których wiedzę zaczerpnął z akt, miałam też wrażenie, jakby biegły psycholog zaczynał mieć wpływ na treść zeznań świadka" (c20).

Wydaje się, że cenią także inne cechy biegłego związane z wykonywaniem przez niego obowiązków. W tym kontekście wysokie notowania ma zaangażowanie biegłych psychologów: „bardzo zaangażowany w pracę, dociekliwy" (c39) oraz czynny udział w realizowanych czynnościach: „faktycznie w czasie przesłuchania jest aktywny, zadaje pytania, czyni notatki (...)" (c10). $\mathrm{W}$ wywiadach podkreślano znaczenie wywiązywania się z przyjętych zobowiązań - odpowiedzialności i terminowości: ,,[jakie problemy pojawiaja się we wspótpracy $z$ biegłymi psychologami? - przyp. aut.] Niepunktualność, zbyt długi czas sporządzania opinii, odwoływanie posiedzeń, co znacznie wydłuża czas postępowania. Jeśli mam wskazać jakieś problemy we współpracy, to są to głównie kwestie związane z niesłownością" (c18).

Wreszcie, wskazywano na znaczenie umiejętności współpracy z osobami przesłuchiwanymi, zwłaszcza nawiązywania kontaktu z osobą badaną: „Obserwując pracę kilku biegłych, zauważyłam, że ich umiejętności w nawiązywaniu kontaktów z osobami są różne. Jedni osiągają to w sposób naturalny, co skutkuje tym, że łatwiej sobie radzą z sytuacją, dzięki czemu przesłuchanie przebiega bez problemów. Inni zachowują dystans, który samemu świadkowi też utrudnia zeznawanie" (c24). 


\section{Jakość opinii biegłego psychologa dotyczaca zeznań świadków}

Biorących udział w badaniu sędziów i prokuratorów zapytano o to, co w ich przekonaniu świadczy o wysokiej lub niskiej jakości opinii sądowo-psychologicznych dotyczących zeznań świadków.

Wydaje się, że kluczową cechą dobrej opinii (a jej brak znamionuje opinię niskiej jakości) jest jej kompletność. Kompletność ta jest rozumiana na kilka sposobów. Po pierwsze, opinia jest kompletna wtedy, gdy zawiera odpowiedzi na wszystkie pytania: „Odpowiada na wszystkie pytania, które zostały zadane biegłemu w postanowieniu. To jest najbardziej istotne. Jeżeli te pytania są w opinii uwzględnione i uszczegółowione, to opinia jest pełna" (c24). Po drugie, opinia jest kompletna wówczas, gdy biegły uwzględnia wszystkie okoliczności mogące mieć istotne znaczenie dla rozstrzygnięcia kwestii, którą postawiono przed biegłym: „Czasami opinia jest niepełna, nie uwzględnia wszystkich okoliczności. Niekiedy biegły skupia się bardziej na kwestii konfabulacji świadka, a pomija jakieś inne okoliczności, które są istotne (...)" (c32). Po trzecie, o kompletności opinii świadczy również uwzględnienie materiału dowodowego udostępnionego biegłemu do opiniowania: „,[opinia niskiej jakości to taka - przyp. aut.] bez analizy wcześniejszych opinii odnoszących się np. do spraw po uchyleniu - biegły w takim przypadku w ogóle nie odniósł się do wcześniejszej opinii, która mogła zawierać inne wnioski niż ta, którą on formułował” (c39) lub: „,...) oceniamy, czy ta opinia uwzględnia inny materiał, który jest dostępny w sprawie, np. dokumentację medyczną" (c6). Po czwarte wreszcie, niekompletne opinie to również takie, które nie zawierają pełnego i wyczerpującego sprawozdania z przeprowadzonych badań: „To były bardzo powierzchowne opinie, bez wyjaśnienia metod badawczych, bez głębszej analizy materiału dowodowego (...)" (c39).

W nawiązaniu do kwestii kompletności (lub braku) opinii pojawiało się zagadnienie przeprowadzenia przez biegłego badań psychologicznych i oparcie opinii wyłącznie na obserwacji przesłuchania świadka, np. „Doceniam to, że biegła sprawdziła np. poziom emocjonalny czy rozwój umysłowy dziecka, a także fakt, że poza wzięciem udziału w przesłuchaniu jeszcze się z nim spotyka" (c25). Wydaje się, że przedstawiciele organów procesowych (choć nie wszyscy) mają świadomość niezbędności tych badań w prawidłowym warsztacie biegłego psychologa opiniującego w sprawach zeznań świadków: „Wydaje mi się, że przed wydaniem takiej kategorycznej opinii, całkowicie wiarygodnej, biegły powinien przeprowadzić badania psychologiczne poza salą rozpraw" (c13) lub inna wypowiedź: „,...) to badanie jest, moim zdaniem, naprawdę cennym źródłem wiedzy dla psychologa" (c23).
Do kwestii niepełności opinii, w szczególności nieuwzględnienia okoliczności istotnych dla rozstrzygnięcia danej kwestii oraz braku pełnego sprawozdania z przeprowadzonych czynności, odnoszą się również te wypowiedzi indagowanych, które określają niskiej jakości opinie mianem schematycznych, lakonicznych lub pobieżnych. Wielu zwracało uwagę na przypadki kopiowania fragmentów lub wręcz całych opinii na potrzeby tej aktualnie przygotowywanej: „Te opinie są wszystkie takie same, jak gdyby powstawały metodą 'kopiuj-wklej' - i to jest chyba ich główna wada (...), widziałem wiele opinii dotyczących oceny prawdziwości zeznań świadka, ale to wszystko jest bardzo płytkie i nijakie" (c11). Niektórzy wręcz wskazują, że biegli posługują się (na dodatek dość niechlujnie) wzorami opinii: „Wszyscy posługujemy się komputerami i opinie są pisane tak jak postanowienia prokuratorskie, sądowe czy wyroki. Wszystko to jest tworzone na powstałych wcześniej wzorach - taki sposób redagowania opinii, wyroków, postanowień czy decyzji generuje możliwe pomyłki, gdy coś, co wpisano w poprzedniej opinii, nie zostanie wykasowane przez piszącego nową opinię" (c59).

Do sprawy niepełności opinii nawiązują również te wypowiedzi, które jako kryterium jakości opinii sądowopsychologicznej dotyczącej zeznań świadków wskazują ich wnikliwość (rozumianą jako odniesienie do zróżnicowanych źródeł wiedzy o osobie badanej, uwzględnienie różnych aspektów ważących na ocenie itp.): „Patrzę najczęściej na to, na ile biegły wnikliwie ocenia daną osobę, czy zwraca uwagę tylko na treść zeznań, czy także na mimikę, na sposób zachowania świadka, na te reakcje pozawerbalne - czy rzeczywiście jego ocena jest całościowa. Zwracam także uwagę na to, czy skupiał się on jedynie na samym udziale w przesłuchaniu, czy też odbywał jeszcze ze świadkiem jakąś inną rozmowę poza salą rozpraw, by móc zorientować się w jego sposobie funkcjonowania? Czy próbował się dowiedzieć, czy była to osoba chora, sięgać do dokumentacji leczenia? To wszystko pozwala mi ocenić, na ile jest to wnikliwa, szczegółowa i drobiazgowa opinia" (c37). Wnikliwości i szczegółowości opinii nie należy jednak mylić z nieuzasadnioną obszernością (spowodowaną zawarciem w opinii elementów zbędnych, niepotrzebnych): „Czasami biegli za dużo w swoich opiniach piszą; skanują czy kserują te zeznania, chcąc podnieść wartość swoich opinii czy próbując dowieść sędziemu, że naprawdę zapoznali się z materiałem. Uważam, że to jest zbędne, bo dla mnie już z treści opinii wynika, czy ktoś się z tym materiałem zapoznał czy nie, czy też zawartość opinii wykracza poza treści tam się znajdujące" (c32).

Wiele wątków w wypowiedziach pytanych w trakcie badania osób odwoływało się do jasności opinii. Opinia jasna to według Tomaszewskiego (1998) taka, która pozwala na prześledzenie sposobu dochodzenia przez biegłego do sformułowanych wniosków końcowych. Wielu 
pytanych wskazywało przy tym na kryterium logicznego powiązania między sprawozdaniem i wnioskami końcowymi opinii: „Na zasadzie prostego wnioskowania: jeżeli mamy określone przesłanki i wyciągamy z nich konkretny, wynikający logicznie wniosek, to wszystko jest w porządku" (c22). Indagowani często podkreślali konieczność właściwego osadzenia $\mathrm{w}$ przeprowadzonych badaniach i podjętych czynnościach oraz uzasadnienia wniosków końcowych opinii: „Obowiązkiem biegłego jest wskazanie, skąd wyciąga takie wnioski. Opinia, oprócz samych wniosków, musi zawierać cały proces dochodzenia do tych wniosków" (c12). W sposób bardziej opisowy, akcentujący również kwestię spójności między częścią sprawozdawczą opinii a wnioskami, precyzuje to poniższa wypowiedź: „Według mnie dobra opinia to taka, w której mam opisane wyniki badania, różne sfery funkcjonowania świadka, jego osobowość, linię życiową i na końcu wnioski sprowadzające się nie tylko do konstatacji, że świadek jest psychologicznie wiarygodny lub nie. Dobre wnioski opinii to takie, które nawiązują do tych sfer poznawczych świadka, które określają zdolność zapamiętywania, a jeśli jest ona niska, to $\mathrm{z}$ jakiego powodu. Wnioski powinny być spójne $\mathrm{z}$ tym, co było wcześniej, ze sprawozdaniem, powinny być poszerzone. Jeśli u kogoś stwierdzono organiczne zmiany w mózgu, to we wnioskach powinna się znaleźć informacja o tym, czy i na co takie zmiany mogą mieć wpływ" (c57). Z tego względu nieakceptowane są opinie psychologiczne takie, jak wskazane w poniższej wypowiedzi: „,...) są i takie, które ograniczają się do tego, że najpierw streszcza się w nich to, co zeznał świadek, a następnie pojawiają się konkluzje, enigmatyczne odpowiedzi na pytania sądu. I takie opinie według mnie niewiele wnoszą, ponieważ wnioski końcowe w żaden sposób nie wynikają z części opisowej" (c40).

Do jasności opinii jako kryterium oceny jej jakości odwoływali się ci sędziowie i prokuratorzy, którzy wskazywali, że zwracają uwagę na klarowność opinii. Symptomem tej czytelności jest niewątpliwie posługiwanie się przez biegłego zrozumiałym językiem: „,Żeby odpowiadała na pytania sądu najpełniej, a przy tym jak najmniej zawile, językiem dosyć prostym" (c51), zrozumiałym dla wszystkich uczestników postępowania: ,(...) żeby była napisana językiem niekoniecznie bardzo naukowym, im prostszym, tym lepiej, bo opinia jest nie tylko dla sądu, ale także dla stron, wszyscy muszą zrozumieć o co chodzi” (c51).

Sprzeczne opinie formułowali indagowani sędziowie i prokuratorzy w odniesieniu do kwestii jednoznaczności wniosków opinii biegłego psychologa. Wielu przedstawicieli organów procesowych szczególnie ceni, gdy biegły jest kategoryczny w swych ocenach, dopuszczający tylko jedną, możliwą interpretację: „większość opinii jest kategoryczna i to jest na pewno bardzo istotne, bo to ułatwia pracę sędziego” (c32) lub: „Najlepsze są opinie, gdy wnioski są kategoryczne. Najgorzej, gdy są rozmyte" (c8). Oczekują również jednoznacznej i stanowczej deklaracji wówczas, gdy nie jest możliwe wydanie opinii kategorycznej: „Jak biegły nie wie, to niech napisze, że nie wie. A przeglądając akta kolegów, przygotowując się na rozprawę, nieraz zauważyłem, że te opinie nie były jednoznaczne. Ja wiem, że czasami się nie da zrobić jednoznacznej opinii, ale wtedy trzeba wyraźnie napisać, że nie jest to możliwe" (c20). Inni badani - odwrotnie - stoją na stanowisku, że kategoryczne wnioski opinii sądowo-psychologicznej dotyczącej zeznań świadków są niedopuszczalne: „W opinii psychologicznej kategoryczne wnioski są nieprofesjonalne" (c43). Ta rozbieżność jest być może pozorna. Czym innym jest niemożność odpowiedzenia na pytanie organu procesowego (gdy na podstawie zgromadzonych danych nie sposób sformułować jednoznacznych wniosków opinii), czym innym zaś nadmierna ostrożność interpretacyjna ze strony biegłego.

Szczególnie ważne dla sędziów i prokuratorów wydaje się niewykraczanie przez biegłego poza zakres jego kompetencji eksperckich. Rozumieją pod tym pojęciem dwie sytuacje - po pierwsze: niewypowiadanie się w kwestiach, które należą do obszaru specjalizacji biegłego z innej dyscypliny: „Weryfikuję tę opinię, rozważając, czy nie wykracza ona poza zakres kompetencji biegłego, czy nie jest potrzebny biegły z innej dziedziny" (c33). Po drugie zaś: niewkraczanie w kompetencje organu procesowego, tzn. nieformułowanie ocen co do stanu faktycznego sprawy: „Nie próbuje umieszczać w opinii rzeczy, o które się go nie pyta, albo do których nie jest powołany. Nie umieszcza swoich opinii co do przedmiotu postępowania" (c48) i niewypowiadanie się w kwestii wiarygodności zeznań konkretnego świadka: „Na pewno opinia nie powinna zawierać takich informacji, że ktoś kłamie lub fałszywie zeznaje, bo tego biegły nie może stwierdzić, to zadanie sędziego. A nieraz pojawiają się takie informacje (...)" (c26). Sędziowie i prokuratorzy w większości są w stanie wskazać, gdzie przebiega granica między kompetencjami organu procesowego a biegłego psychologa: „Jeśli psycholog w sposób kategoryczny mówi, że w jakimś zakresie dana osoba jest wiarygodna albo nie, to takie stwierdzenie wzbudza moją ostrożność. Wydaje mi się, że psycholog powinien wskazać jakieś czynniki, które za tym przemawiają, lub zasugerować pewne rzeczy, a resztę oddać mojej ocenie. Myślę, że między naszymi kompetencjami powinna być jakaś granica, której nie powinniśmy przekraczać" (c16). Można również odnieść wrażenie, że, przynajmniej niektórzy, nie dostrzegają różnic między oceną prawną i psychologiczną, a różnice sprowadzają do używania właściwego słownictwa: „Biegli muszą tylko zachować właściwą ostrożność, żeby - jak to niekiedy wynika też ze stosowanego słownictwa - nie stawiali się w roli sądu, twierdząc: 'uznaję świadka za wiarygodnego', lecz tylko napisali czy powiedzieli: 'spełnia kryteria psychologicznej 
wiarygodności"” (c19). Niestety, niektórzy - zwłaszcza prokuratorzy - wręcz wprost oczekują od biegłych dokonania oceny wiarygodności: „Najczęściej oczekuje się, aby zostało napisane wprost, czy to jest wiarygodne, czy nie. To stwierdzenie zawsze pada, ale dobrze jest, jeżeli zostanie wcześniej wytłumaczone dlaczego" (c23).

O jakości opinii może też świadczyć to, czy opinia jest dla organu procesowego przekonująca i czy będzie taka dla sądu na etapie rozprawy głównej: „Kiepska opinia to taka, która mnie do niczego nie przekonuje. Albo jeśli ja mam wątpliwości po jej lekturze - wtedy wiem, że sąd tym bardziej będzie je miał" (c58).

\section{Dyskusja wyników}

Zaprezentowane badania jakościowe potwierdzają dotychczasowe doniesienia dotyczące kryteriów wyboru biegłych przez przedstawicieli organów procesowych. Z kryteriami tymi korespondują zresztą wypowiedzi indagowanych dotyczące pożądanych cech biegłych psychologów, w których dominuje odwołanie do ich merytorycznych kompetencji - specjalizacji, doświadczenia zawodowego, rzetelnego wykonywania obowiązków biegłego czy umiejętności współpracy tak z organami procesowymi, jak i stronami i uczestnikami procesu. Deklarowane kierowanie się kompetencjami biegłych psychologów przy ich wyborze znajduje też potwierdzenie $\mathrm{w}$ badaniach prowadzonych $\mathrm{w}$ innych krajach i systemach prawnych, np. w Australii (Gianvanni, Sharman, 2017). Wspomniane badania australijskie wskazują jednak, że choć prawnicy deklarują, że kompetencje są dla nich kluczowe przy wyborze biegłego, to nie mają wiedzy o tym, w jaki sposób psycholog może uzyskać pożądaną w ich ocenie specjalizację kliniczną lub sądową.

Opinie wyrażone w niniejszych badaniach korespondują z doniesieniami z badań Fundacji Forensic Watch (2015) dotyczącymi oceny instytucji biegłego. Z badań ankietowych przeprowadzonych z udziałem sędziów, prokuratorów i adwokatów dwa najpoważniejsze problemy w kontekście funkcjonowania instytucji biegłego sądowego to: błędy merytoryczne $\mathrm{w}$ sprawozdaniach z wykonywanych przez biegłych badań (np. niejasność wywodu, niejednoznaczne wnioski, niepełność opinii) oraz długi okres oczekiwania na opinie biegłych.

Wydaje się, że kierowanie się w wyborze obiegowymi opiniami lub poleceniem ze strony kolegów jest powszechną praktyką nie tylko w Polsce (Gianvanni, Sharman, 2017). Trudno mieć o to pretensje do sędziów czy prokuratorów, skoro system funkcjonowania biegłych sądowych ani nie promuje kandydatów o najwyższych kompetencjach merytorycznych, ani nie przewiduje efektywnych narzędzi odsuwania od czynności osób niewywiązujących się prawidłowo z powierzonej funkcji. Wydaje się, że niską ocenę systemu funkcjonowania biegłych sądowych potwierdza również wyrażane przez indagowanych przekonanie, że dla biegłych sądowych „zarezerwowane” są sprawy mniej skomplikowane.

W swoich wypowiedziach dotyczących jakości opinii sądowo-psychologicznej sędziowie i prokuratorzy wyraźnie nawiązywali do takich właściwości opinii, które odpowiadają prawnym kryteriom oceny opinii wskazanym w art. 201 k.p.k., czyli (nie)pełności, (nie)jasności i (nie)sprzeczności opinii, rozwiniętym w orzecznictwie (np. wyrok SN z dnia 7.10.2009, III KK 12/09) i literaturze prawniczej (Gaberle, 2010; Tomaszewski, 1998; Witkowska, 2013). Próżno szukać odniesień do prezentowanych w literaturze kryteriów metodologicznych oceny opinii sądowo-psychologicznej. Istnieje zatem potrzeba szkolenia przedstawicieli organów procesowych z zakresu dostępnych sposobów pogłębionej oceny tego typu opinii.

Wskazywane przez udzielających wywiadu cechy dobrej (i złej) jakości opinii psychologicznych dotyczących zeznań świadków nie są charakterystyczne wyłącznie dla polskiej praktyki. W badaniach australijskich wskazywano na wagę właściwego uzasadnienia dla formułowanych wniosków, które znajdują oparcie $\mathrm{w}$ przeprowadzonych badaniach, niewykraczanie poza zakres własnych kompetencji, obiektywizmu biegłego oraz prostego i przejrzystego języka opinii (Gianvanni, Sharman, 2017; Freckelton, Reddy, Selby, 1999). Można więc wysnuć ostrożny wniosek, że pewne problemy opiniodawstwa sądowego są uniwersalne.

$\mathrm{Na}$ szczególną uwagę zasługują wypowiedzi badanych $\mathrm{w}$ odniesieniu do kwestii związanej $\mathrm{z}$ granicami między kompetencjami biegłych psychologów a organów procesowych, dla niektórych przedstawicieli tych ostatnich rozumianej wyłącznie jako kwestia nomenklatury. Jest ona jednak bardziej złożona. W orzecznictwie dominuje przekonanie, że ocena wiarygodności zeznań świadka należy wyłącznie do sądu orzekającego, który dokonuje jej na podstawie całokształtu materiału dowodowego (np. wyrok SA w Krakowie z dn. 21.10.2014, II Aka 149/14). Ocena wiarygodności zeznań nie należy do kompetencji biegłego psychologa, innymi słowy - rolą psychologa nie jest wypowiadanie się, na ile zeznania te odpowiadają rzeczywistemu przebiegowi zdarzenia (np. wyrok SA w Krakowie z dnia 15.012003, II AKa 360/02). Analogicznie wypowiedział się SA w Katowicach, wskazując, że biegły psycholog nie jest uprawniony do formułowania kardynalnych ocen co do wartości dowodowej zeznań świadka, skoro wyprowadzone przez niego w opinii wnioski nie mogą odnosić się - poza przypadkami patologicznymi - do wypowiadania ocen odnoszących się do możliwości kłamliwości tych zeznań, bowiem wnioski w tym przedmiocie mogą być uzależnione od wyników interpretacji innych dowodów ujawnionych w sprawie (wyrok SA w Katowicach z dnia 12.05.2005, II Aka 303/04). Trzeba jednak podkreślić, 
niejako w kontrze do przytoczonego orzeczenia, że nie należy wiarygodności zeznań (lub jej braku) utożsamiać z ich prawdziwością lub szczerością (Maciejski, 2009). Pełna ocena zeznań powinna uwzględniać wszystkie trzy wspomniane elementy, które nie są ze sobą tożsame. Prawdziwość to zgodność treści zeznań z faktycznym przebiegiem zdarzenia. Szczerość należy rozumieć jako zgodność treści zeznań z subiektywnym przekonaniem o prawdziwości lub fałszywości złożonej relacji. Wreszcie - wiarygodność to przypisane przez organ procesowy prawdopodobieństwo, że zeznanie świadka odzwierciedla rzeczywistość. Przekonanie to organ prowadzący postępowanie formułuje na podstawie oceny całości zgromadzonego w sprawie materiału dowodowego (Wojciechowski, 2016). Decyzja organu procesowego o przypisaniu zeznaniom określonego poziomu wiarygodności może być niezależna $z$ jednej strony od intencji świadka co do szczerego lub kłamliwego przedstawienia zdarzenia, z drugiej zaś - od obiektywnej prawdziwości jego relacji (Wojciechowski, 2016).

Prawna ocena zeznań świadka powinna obejmować prawdziwość, szczerość i wiarygodność zeznań, ze szczególnym wskazaniem faktu, że ocena wiarygodności jest wyłączną domeną organów procesowych. Z kolei ocena psychologiczna, dokonywana przez biegłego psychologa w ramach opinii sądowo-psychologicznej, ma charakter pomocniczy - ma ułatwiać organom procesowym formułowanie ocen, stwarzać odpowiednie warunki do oceny prawnej zeznań, koncentrować się na poszukiwaniu zmiennych determinujących najważniejsze cechy relacji (Wojciechowski, 2016).

Warto również zwrócić uwagę na fakt, że pytani w badaniu sędziowie i prokuratorzy byli dość zgodni co do niezbędności przeprowadzenia przez biegłego psychologa badań psychologicznych obok udziału w samym przesłuchaniu w celu wydania opinii sądowo-psychologicznej. Co prawda art. $192 \S 4$ k.p.k. wskazuje na możliwość (a nie obowiązek) przeprowadzenia przez biegłego badań psychologicznych świadka, niemniej uznać należy, że ich brak jest podstawą uznania opinii za niepełną (Jaśkiewicz-Obydzińska, Wach, 2013). Konieczność przeprowadzenia przez biegłego badań psychologicznych jest wręcz podstawową zasadą opracowywania opinii dla celów sądowych (Jaśkiewicz-Obydzińska, Wach, 2013).

Zaprezentowane badania, choć stanowią istotne uzupełnienie dotychczasowej wiedzy na temat kryteriów wyboru biegłych psychologów oraz sposobu oceny jakości ich opinii dotyczących zeznań przez przedstawicieli organów procesowych, nie uwzględniały perspektywy drugiej strony $-\mathrm{tj}$. nie obejmowały wywiadów pogłębionych z biegłymi psychologami. Poznanie wzajemnych punktów widzenia mogłoby przyczynić się do usprawnienia komunikacji i współpracy między prawnikami i psychologami. Skonfrontowanie wzajemnych oczekiwań i możliwości ich spełnienia $\mathrm{z}$ obu stron wymaga jednak jeszcze rzetelnego poznania aktualnej praktyki opiniowania sądowo-psychologicznego w kwestiach związanych z psychologiczną oceną zeznań, np. w drodze badań aktowych.

\section{Podziękowania}

Badania zostały sfinansowane przez Narodowe Centrum Nauki (grant ID 2015/19/D/HS5/01241). 